Review Article

\title{
Evaluating Lignin-Rich Residues from Biochemical Ethanol Production of Wheat Straw and Olive Tree Pruning by FTIR and 2D-NMR
}

\author{
José I. Santos, ${ }^{1}$ Raquel Martín-Sampedro, ${ }^{2}$ Úrsula Fillat, ${ }^{2}$ José M. Oliva, ${ }^{3}$ María J. Negro, ${ }^{3}$ \\ Mercedes Ballesteros, ${ }^{3}$ María E. Eugenio, ${ }^{2}$ and David Ibarra ${ }^{2}$ \\ ${ }^{1}$ NMR Facility of Research (SGIker), Joxe Mari Korta Center, University of the Basque Country (UPV/EHU), \\ Avenida Tolosa 72, 20018 San Sebastián, Spain \\ ${ }^{2}$ INIA-CIFOR, Forestry Products Department, Cellulose and Paper Laboratories, Ctra de la Coruña Km 7.5, 28040 Madrid, Spain \\ ${ }^{3}$ CIEMAT, Renewable Energy Division, Biofuels Unit, Avenida Complutense 40, 28040 Madrid, Spain
}

Correspondence should be addressed to David Ibarra; ibarra.david@inia.es

Received 15 December 2014; Revised 24 February 2015; Accepted 5 March 2015

Academic Editor: Alireza Ashori

Copyright (C) 2015 José I. Santos et al. This is an open access article distributed under the Creative Commons Attribution License, which permits unrestricted use, distribution, and reproduction in any medium, provided the original work is properly cited.

\begin{abstract}
Lignin-rich residues from the cellulose-based industry are traditionally incinerated for internal energy use. The future biorefineries that convert cellulosic biomass into biofuels will generate more lignin than necessary for internal energy use, and therefore valueadded products from lignin could be produced. In this context, a good understanding of lignin is necessary prior to its valorization. The present study focused on the characterization of lignin-rich residues from biochemical ethanol production, including steam explosion, saccharification, and fermentation, of wheat straw and olive tree pruning. In addition to the composition and purity, the lignin structures (S/G ratio, interunit linkages) were investigated by spectroscopy techniques such as FTIR and 2D-NMR. Together with the high lignin content, both residues contained significant amounts of carbohydrates, mainly glucose and protein. Wheat straw lignin showed a very low $S / G$ ratio associated with $p$-hydroxycinnamates ( $p$-coumarate and ferulate), whereas a strong predominance of $S$ over $\mathrm{G}$ units was observed for olive tree pruning lignin. The main interunit linkages present in both lignins were $\beta-O-4^{\prime}$ ethers followed by resinols and phenylcoumarans. These structural characteristics determine the use of these lignins in respect to their valorization.
\end{abstract}

\section{Introduction}

Fossil fuel exhaust and greenhouse gas (GHG) effects make renewable biofuels, such as bioethanol and biodiesel, attractive options for oil replacement. In recent years, some international policies, such as the European Union Directive 2009/28/CE, have been adopted to gradually replace fossil fuels by biomass-based fuels or biofuels [1]. In this context, the progress towards the production of bioethanol from lignocellulosic biomass is fundamental.

Lignocellulosic biomass is an abundant, cheap, and widely distributed feedstock. Among different lignocellulosic raw materials, agriculture residues such as wheat straw and olive tree pruning have shown a great potential for bioethanol production $[2,3]$. Wheat straw is an abundant lignocellulosic biomass from wheat production, mainly in Europe. The average yield of straw is $1.1 \mathrm{Kg} / \mathrm{Kg}$ of wheat grain [4], with a world production of wheat straw estimated to be around 680 million tons in 2011 [5]. Generally, wheat straw is used as animal feeding and bedding straw, being the remainder burned or left on the land to fertilize the soil. Regarding olive tree pruning, it is a yearly generated lignocellulosic agricultural residue, largely available in Mediterranean countries, with a production estimated at $3000 \mathrm{~kg} / \mathrm{ha}$ worldwide [4]. This residue, composed mainly of a woody fraction and a remaining fraction consisting of leaves, pith, and young stems, is usually disposed of either by burning or by grinding and scattering on the field.

Biochemical ethanol production process is based on the utilization of carbohydrates contained in the plant cell 
walls. The conversion process comprises the following steps: pretreatment, enzymatic hydrolysis of cellulose and hemicelluloses, sugars fermentation, separation of lignin-rich solid stream, and distillation [4]. About $40 \%$ of the residual lignin stream is necessary in order to obtain energy for processing plant, mainly by combustion [6]. The rest of lignin could be transformed into value-added products including biobased aromatic chemicals, as well as building blocks for materials and fuels [7]. In the same way, the traditional pulp and paper industry is looking for new value-added products from their side-stream lignins. Thus, the conversion of these processes into biorefineries will help to enhance the profitability of bioethanol plants and paper mills.

Lignin is a complex three-dimensional polymer built up of $p$-hydroxyphenyl $(\mathrm{H})$, guaiacyl $(\mathrm{G})$, and syringyl (S) phenylpropanoid units, derived from the corresponding hydroxycinnamyl alcohols ( $p$-coumaryl, coniferyl, and sinapyl alcohols) [8], which give rise to a variety of subunits including $\mathrm{C}-\mathrm{C}$ and ether bonds. Due to the complexity and heterogeneity of this polymer, a precise understanding of the lignin composition and structure is needed in order to determine the feasibility of a specific application and to select a better lignin source for a particular product. In this sense, spectroscopy techniques such as Fourier transform infrared (FTIR) and two-dimensional nuclear magnetic resonance (2D-NMR) are methods that offer an in-depth knowledge of the lignin structure. FTIR gives an overall picture on the lignin purity and composition [9], whereas 2D-NMR provides detailed information on the various lignin moieties and interunit linkages [10]. The use of these techniques has been successfully applied for the analysis of side-stream lignins from pulp and paper industry prior to their valorization [11-16]. However, little information by these spectroscopy techniques is available for bioethanol process lignins.

In this study, two lignin-rich residues from biochemical ethanol production, including steam explosion pretreatment, saccharification, and fermentation, of wheat straw and olive tree pruning, were characterized. In addition to the purity and composition, the lignin structures (S/G ratio, interunit linkages) were analyzed using FTIR and 2D-NMR as a prior step in the development of value-added products. Several applications of studied lignins were considered based on their structural characteristics.

\section{Materials and Methods}

2.1. Raw Materials. Wheat straw (Triticum aestivum L.), $10 \%$ moisture, was supplied by DONG Energy (Skærbæk, Denmark). Olive tree pruning (Olea europaea), 10\% moisture, was provided by University of Jaén (Spain). The biomass samples were milled to a particle size smaller than $10 \mathrm{~mm}$, homogenized, and stored until being used. On average, wheat straw contained the following (\% dry weight): cellulose, 40.2; hemicelluloses, 25.6 (xylan, 22.3; arabinan, 3.3); acidinsoluble lignin, 18.6; extractives, 6.3; and ash, 5.2. Olive tree pruning showed the following composition (\% dry weight): cellulose, 22.5; hemicelluloses, 14.2 (xylan, 10.0; galactan, 1.3; arabinan, 2.2; and mannan 0.7); acid-insoluble lignin, 16.6; extractives, 31.4 (27.5 water extract (of which 7.9 is glucose) and 3.9 ethanol extract); and ash, 3.4.

2.2. Steam Explosion Pretreatment. Wheat straw, without previous impregnation, was pretreated in a steam explosion pilot plant (Mini IBUS equipment, Technical University of Denmark, Risø Campus, Denmark) as previously described [17]. Steam explosion of olive tree pruning, with previous water impregnation ( $1 \% \mathrm{w} / \mathrm{w}$, overnight), was carried out in a prototype small plant (CIEMAT, Spain) as previously described [18]. After the steam explosion pretreatment, the materials were recovered, cooled, and filtered for solids recovery. The solids fractions were thoroughly washed obtaining the water insoluble solids (WIS) fractions. Temperature and residence time conditions of the pretreatment for wheat straw $\left(210^{\circ} \mathrm{C}, 10 \mathrm{~min}\right)$ and olive tree pruning $\left(240^{\circ} \mathrm{C}, 5 \mathrm{~min}\right)$ were based on optimal sugars recovery and enzymatic hydrolysis yield of each raw material $[3,19]$.

2.3. Enzymes. A standard mixture of Celluclast $1.5 \mathrm{~L}$ and Novozyme 188, both provided by Novozymes (Bagsvaerd, Denmark), was used for saccharification. Celluclast $1.5 \mathrm{~L}$ is a cellulase preparation with some xylanase activity, but practically no $\beta$-glucosidase activity; therefore, supplementation with Novozyme 188, which mainly presents $\beta$-glucosidase activity, is typically applied in bioethanol production process. Overall cellulase activity was determined using filter paper (Whatman number 1 filter paper strips), and $\beta$-glucosidase activity was measured using cellobiose as substrate [20].

One unit of enzyme activity was defined as the amount of enzyme that transforms $1 \mu \mathrm{mol}$ of substrate per minute.

2.4. Microorganism. Saccharomyces cerevisiae (Fermentis Ethanol Red, Marcq en Baroeul Cedex, France) was used as fermenting microorganism. Active cultures for inoculation were obtained in $100 \mathrm{~mL}$ flasks with $50 \mathrm{~mL}$ of growth medium containing $30 \mathrm{~g} / \mathrm{L}$ glucose, $5 \mathrm{~g} / \mathrm{L}$ yeast extract, $2 \mathrm{~g} / \mathrm{L} \mathrm{NH}_{4} \mathrm{Cl}$, $1 \mathrm{~g} / \mathrm{L} \mathrm{KH}_{2} \mathrm{PO}_{4}$, and $0.3 \mathrm{~g} / \mathrm{L} \mathrm{MgSO}_{4} \cdot 7 \mathrm{H}_{2} \mathrm{O}$. After $16 \mathrm{~h}$ on a rotary shaker at $150 \mathrm{rpm}$ and $35^{\circ} \mathrm{C}$ the precultures were centrifuged at $9000 \mathrm{rpm}$ for $10 \mathrm{~min}$. Supernatant was discarded and cells were washed once with distilled water and then diluted to obtain the inoculum level needed.

2.5. Simultaneous Saccharification and Fermentation Process (SSF). SSF processes with wheat straw and olive tree pruning WIS fractions were carried out at the optimum temperature $\left(35^{\circ} \mathrm{C}\right)$ and time conditions $(72 \mathrm{~h})$ in $100 \mathrm{~mL}$ erlenmeyer containing sodium acetate buffer $0.1 \mathrm{M}(\mathrm{pH} 4.8)$ supplemented with the growth medium without glucose described above $[3,19]$. A solids concentration of $20 \%(w / w)$ with an enzyme loading of $30 \mathrm{FPU} / \mathrm{g}$ glucan of Celluclast $1.5 \mathrm{~L}$ $(65 \mathrm{FPU} / \mathrm{mL}$ and $660 \mathrm{IU} / \mathrm{mL}$ of cellulase and xylanase activities, resp.), $30 \mathrm{IU} / \mathrm{g}$ glucan of Novozyme 188 (664 IU/mL of $\beta$ glucosidase activity), and $0.25 \mathrm{~g} / \mathrm{L}$ (dry weight) of inoculum was used for wheat straw WIS fraction. The same enzyme loading of Celluclast 1.5L and Novozyme 188 and inoculum size were used for olive tree pruning WIS fraction at a solids concentration of $30 \%(\mathrm{w} / \mathrm{w})$. 
Prior to SSF, a presaccharification step was performed by incubating the cellulolytic mixture and the pretreated biomass samples at $50^{\circ} \mathrm{C}$ for $8 \mathrm{~h}$ previous to inoculation.

After SSF, the lignin-rich fermentation residues were rinsed with water and dried overnight at $60^{\circ} \mathrm{C}$ according to Sannigrahi and Ragauskas [6].

2.6. Analytical Methods. Chemical composition of raw and pretreated materials (WIS) and lignin-rich residues was determined using the Laboratory Analytical Procedures for biomass analysis provided by the National Renewable Energies Laboratory [21]. Carbohydrate content was quantified by high-performance liquid chromatography (HPLC) in a Waters chromatograph equipped with a refractive index detector (Waters, Milford, MA). A CARBOSep CHO-682 carbohydrate analysis column (Transgenomic, San Jose, CA) operated at $80^{\circ} \mathrm{C}$ with ultrapure water as a mobile-phase $(0.5 \mathrm{~mL} / \mathrm{min})$ was employed for the separation. Sugars content in SSF was also measured by HPLC.

The total nitrogen content of the lignin residues was determined by the conventional Kjeldahl method [22].

2.7. FTIR Analyses. FTIR spectra of lignin-rich residues were obtained using a JASCO FT/IR 460 Plus spectrometer, equipped with an accessory single reflection diamond, operating with a resolution of $1 \mathrm{~cm}^{-1}, 400$ scans, and a spectral range of $4000-600 \mathrm{~cm}^{-1}$. FTIR bands were assigned by comparison with those reported in the literature [9, 16, 23-25]. For $S / G$ ratio estimation the intensities of the bands around $1320 \mathrm{~cm}^{-1}$ (S units) and $1268 \mathrm{~cm}^{-1}$ (G units) were estimated, after resolution enhancement (subtraction of $\times 1000$ s derivative), moving-average smoothing $(\times 100)$, and baseline correction between valleys ca. 1401 and $1172 \mathrm{~cm}^{-1}$ [26].

2.8. NMR Spectroscopy. NMR spectra were recorded at $25^{\circ} \mathrm{C}$ in a Bruker AVANCE $500 \mathrm{MHz}$ equipped with a z-gradient double resonance probe. Around $40 \mathrm{mg}$ of lignin-rich residues was dissolved in $0.75 \mathrm{~mL}$ of deuterated dimethylsulfoxide (DMSO- $d_{6}$ ) and HSQC (heteronuclear single quantum correlation) experiment was recorded. The spectral widths for the HSQC were $5000 \mathrm{~Hz}$ and $13200 \mathrm{~Hz}$ for the ${ }^{1} \mathrm{H}$ and ${ }^{13} \mathrm{C}$ dimensions, respectively. The number of collected complex points was 2048 for ${ }^{1} \mathrm{H}$-dimension with a recycle delay of $5 \mathrm{~s}$. The number of transients for the HSQC spectra was 64, and 256 time increments were always recorded in ${ }^{13} \mathrm{C}$ dimension. The $J$-coupling evolution delay was set to $3.2 \mathrm{~ms}$. Squared cosine-bell apodization function was applied in both dimensions. Prior to Fourier transform the data matrixes were zero filled up to 1024 points in the ${ }^{13} \mathrm{C}$-dimension. Residual DMSO (from DMSO- $d_{6}$ ) was used as reference for chemical shifts. Two-dimensional NMR cross signals were assigned by comparison with those reported in the literature [5, 10-15, 24, 27-32]. Semiquantitative analysis of the HSQC cross signal intensities was performed [33]. Volume integration of the cross signals was performed (without internal standard) separately for the different regions of the HSQC spectra, which contain signals that correspond to chemically analogous carbon-proton pairs. In the aliphatic oxygenated region, interunit linkages were estimated from $\mathrm{C}_{\alpha}-\mathrm{H}_{\alpha}$ correlations to avoid possible interference from homonuclear ${ }^{1} \mathrm{H}-{ }^{1} \mathrm{H}$ couplings, and the relative abundance of side chains involved in interunit linkages and terminal structures was calculated (with respect to total side chains). In the aromatic region, $\mathrm{C}_{2}-\mathrm{H}_{2}$ correlations from $\mathrm{H}, \mathrm{G}$, and $\mathrm{S}$ lignin units and from $p$-coumarate and ferulate were used to estimate their relative abundances.

\section{Results and Discussion}

3.1. Pretreatment and SSF Process: Chemical Composition. The biochemical platform, based on the enzymatic hydrolysis and the subsequent fermentation by microorganisms of the carbohydrates contained in the plant cell walls, has been considered the most promising technology for lignocellulosic bioethanol production [4]. This bioconversion platform requires a preliminary pretreatment of lignocellulose to increase cellulose accessibility to the hydrolytic enzymes and consequently to improve the enzymatic hydrolysis and increase the fermentable sugars yields [34]. Among the different pretreatment methods developed to date, steam explosion is one of the most widely exploited pretreatments. During this process, water at high temperature and pressure causes an autocatalyzed cleavage of glycosidic bonds in hemicelluloses and lignin-hemicelluloses linkages. This along with the production of acetic acid from acetyl groups facilitates the removal of hemicelluloses from the plant cell wall, making cellulose more accessible to enzymes [34]. These effects could be seen in wheat straw and olive tree pruning after being subjected to steam explosion pretreatment (Table 1). Compared to cellulose content of both untreated materials ( $40.2 \%$, wheat straw; $22.5 \%$, olive tree pruning), pretreatment increased the cellulose proportion in their respective WIS fractions (49.7\%, wheat straw; $39.2 \%$ olive tree pruning) due to the extensive removal of hemicelluloses content (from $25.6 \%$ of untreated wheat straw to $14.8 \%$ of WIS fraction; from $14.2 \%$ of untreated olive tree pruning to $1.6 \%$ of WIS fraction). It was also clear that the relative lignin content increased after pretreatment (from $18.6 \%$ of untreated wheat straw to $23.5 \%$ of WIS fraction; from $14.2 \%$ of untreated olive tree pruning to $48.0 \%$ of WIS fraction). This lignin increment was attributed not only to the removal of hemicelluloses but also to the accumulation of nonlignin-based material formed by acid catalyzed condensation of polysaccharides or extractives during pretreatment $[3,35]$. In this regard, particularly high lignin content was observed in the WIS fraction from olive tree pruning, value that may be interfering with the high content of extractives (31.4\%) from raw material.

Simultaneous saccharification and fermentation (SSF) process has been one of the most successful methods for lignocellulosic bioethanol production [4]. During this process, the glucose released by the action of hydrolytic enzymes is converted directly to ethanol by the fermenting microorganism, minimizing the end-product inhibition of enzymes caused by cellobiose and glucose accumulation [4]. Then, the SSF process was carried out with the WIS fractions from wheat straw and olive tree pruning at optimum 
TABLE 1: Composition of WIS fractions and lignin-rich residues.

\begin{tabular}{|c|c|c|c|c|c|}
\hline \multicolumn{3}{|c|}{ WIS } & \multicolumn{3}{|c|}{ Lignin-rich residue } \\
\hline $\begin{array}{l}\text { Composition (\% dry } \\
\text { weight) }\end{array}$ & Wheat straw & Olive tree pruning & $\begin{array}{l}\text { Composition ( } \% \text { dry } \\
\text { weight) }\end{array}$ & Wheat straw & Olive tree pruning \\
\hline Cellulose & 49.7 & 39.2 & Glucose & 13.8 & 7.1 \\
\hline Hemicelluloses & 14.8 & 1.6 & Xylose & 0.9 & 0.0 \\
\hline \multirow[t]{4}{*}{ Lignin } & 23.5 & 48.0 & Galactose & 0.1 & 0.1 \\
\hline & & & Arabinose & 0.0 & 0.6 \\
\hline & & & Mannose & 1.0 & 0.0 \\
\hline & & & Lignin & 69.3 & 77.0 \\
\hline
\end{tabular}

Enzymatic hydrolysis yields of $75 \%$ and $50 \%$ for wheat straw and olive tree pruning, respectively.

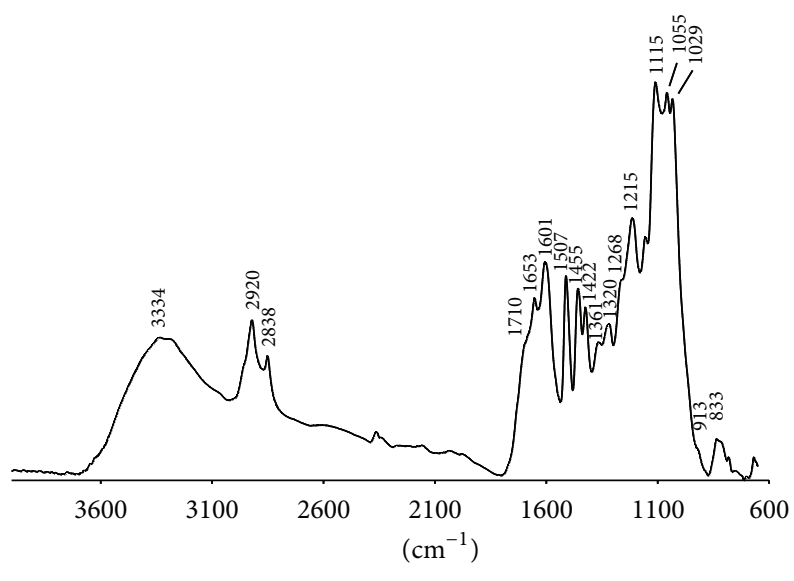

(a)

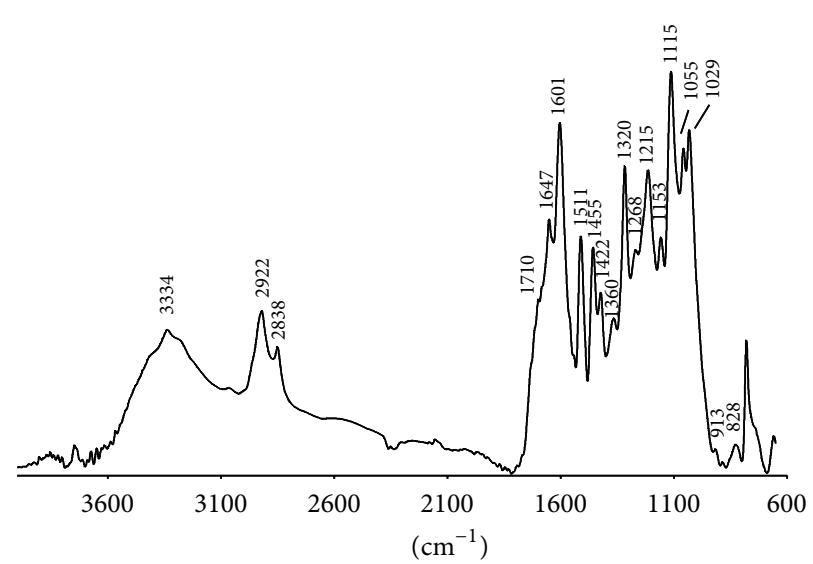

(b)

FIGURE 1: FTIR spectra, 4000-600 $\mathrm{cm}^{-1}$ region, of the lignin-rich residues from wheat straw (a) and olive tree pruning (b) WIS fractions.

conditions based on enzymatic hydrolysis yields [3, 19]. Despite the higher severity factor $\log \left(R_{o}\right)\left(R_{o}=\right.$ time $*$ $\left.e^{[\text {Temperature-100/4.75] }}\right)$ of the steam explosion pretreatment on olive tree pruning (4.82), compared to wheat straw (4.23), the enzymatic hydrolysis yield of the WIS fraction from olive tree pruning was lower $(50 \%)$ than that of wheat straw (75\%). It could be explained by the condensation reactions between extractives and acid-insoluble lignin during steam explosion of olive tree pruning, mentioned above, hindering the accessibility of cellulose and consequently lowering the successive enzymatic hydrolysis yield [36]. As expected, the SSF process concentrated the lignin in both fermentation residues, showing lignin content of $69 \%$ and $77 \%$ for wheat straw and olive tree pruning, respectively (Table 1). Nevertheless, certain sugars, mainly glucose, still remained in both residues ( $15.8 \%$, wheat straw; $7.8 \%$ olive tree pruning) together with a high nitrogen content $(1.1 \%$ wheat straw; $0.8 \%$ olive tree pruning), which indicates the presence of protein residues from hydrolytic enzymes used for saccharification. This contamination by sugars and protein impurities may significantly affect the valorization of these residual lignins. Impurities can produce the formation of undesirable byproducts, result in lower yields, and lead to deterioration in the properties of final products. Then, several lignin purification methods based on enzymatic treatments or acid/base extractions have been proposed [37].

3.2. FTIR Spectral Analysis. Figure 1 shows the FTIR spectra of the lignin residues resulting from SSF process of wheat straw and olive tree pruning WIS fractions. According to the chemical composition reported above, these spectra were clearly dominated by lignin bands. The wide band observed around $3334 \mathrm{~cm}^{-1}$ represented the $\mathrm{O}-\mathrm{H}$ stretching vibration in aromatic and aliphatic structure, and the bands at 2926 and $2838 \mathrm{~cm}^{-1}$ were due to a $\mathrm{C}-\mathrm{H}$ vibration sketch in the $\mathrm{CH}_{2}$ and $\mathrm{CH}_{3}$ groups, respectively. The bands at $1710 \mathrm{~cm}^{-1}$ (shoulder) and $1653-1647 \mathrm{~cm}^{-1}$ represented the $\mathrm{C}=\mathrm{O}$ bonds in nonconjugated and conjugated ketones, respectively. Nevertheless, the latter also may be associated with carbonyl stretching in amide bonds from hydrolytic enzymes used for saccharification [23]. The bands at 1601, 1507, and $1422 \mathrm{~cm}^{-1}$ were attributed to aromatic skeleton vibrations, whereas the band at $1455 \mathrm{~cm}^{-1}$ corresponded to the $\mathrm{C}-\mathrm{H}$ asymmetric vibrations and deformation (asymmetric in methyl and methylene) was also observed. The bands at $1320 \mathrm{~cm}^{-1}$ 
(aromatic ring breathing, $\mathrm{S}$ and $\mathrm{G}_{\text {condensed }}$ units), $1268 \mathrm{~cm}^{-1}$ (guaiacyl ring breathing with $\mathrm{C}=\mathrm{O}$ stretching), and $1215 \mathrm{~cm}^{-1}$ (ring breathing with $\mathrm{C}-\mathrm{C}, \mathrm{C}-\mathrm{O}$, and $\mathrm{C}=\mathrm{O}$ stretching) were also present. Moreover, the bands at 1115 and $1029 \mathrm{~cm}^{-1}$ arose from the aromatic in plane $\mathrm{C}-\mathrm{H}$ bending deformation for $\mathrm{S}$ and $\mathrm{G}$ type lignin, respectively. Finally, the band at $913 \mathrm{~cm}^{-1}$ was indicative of aromatic $\mathrm{C}-\mathrm{H}$ out-of-plane bending in $\mathrm{G}$ units, whereas the band at 833 represented $\mathrm{C}-\mathrm{H}$ out-of-plane bending in positions 2 and 6 of $S$ units and all positions of $H$ units. The intensity differences of the lignin bands observed in both spectra reflected S/G values very differently, revealing the presence of a $G$ type lignin in wheat straw (S/G ratio of 0.5 ) and a $S$ type lignin in olive tree pruning ( $/ \mathrm{G}$ ratio of 5.1).

The remaining sugars content of the lignin-rich residues was also visible in both spectra, revealed by different bands at $1153,1115,1055$, and $1029 \mathrm{~cm}^{-1}$. The $\mathrm{C}-\mathrm{O}$ asymmetric band was observed at $1153 \mathrm{~cm}^{-1}$, while $1115 \mathrm{~cm}^{-1}$ is associated with the $\mathrm{C}-\mathrm{OH}$ skeletal vibration characteristic of cellulose. The absorption band at $1055 \mathrm{~cm}^{-1}$ is an effect of the C-O-C ether linkage of the skeletal vibration of both pentose and hexose unit contribution from hemicellulose and cellulose. Finally, $1029 \mathrm{~cm}^{-1}$ is attributed to $\mathrm{C}-\mathrm{O}$ stretching vibration characteristic of cellulose [38].

3.3. 2D-NMR Spectral Analysis: 2D-NMR Spectra. HSQC NMR spectra of the lignin-rich residues also showed the predominance of lignin signals together with the remaining sugars and some protein contamination (Figure 2). The main structural characteristics of both lignins, including different units linked by ether and $\mathrm{C}-\mathrm{C}$ bonds, and carbohydrates are represented in Figure 3, and their corresponding cross signals listed in Table 2.

The HSQC spectra showed three regions corresponding to aliphatic, oxygenated aliphatic, and aromatic ${ }^{13} \mathrm{C}-{ }^{1} \mathrm{H}$ correlations (Figure 2). No cross signals were observed in the $\delta_{\mathrm{C}} 150-205 \mathrm{ppm}$ region (i.e., not shown in Figure 2). The nonoxygenated aliphatic region (around $\delta_{\mathrm{C}} / \delta_{\mathrm{H}} 0-50 / 0-$ $4.5 \mathrm{ppm}$ ) showed a wide variety of saturated aliphatic moieties with relatively high intensities, especially in the olive tree pruning spectrum. Some strong signals in this area $\left(\delta_{\mathrm{H}}\right.$ 0.8 and $\left.\delta_{\mathrm{H}} 1.2-1.3\right)$ correspond to extractives, mainly of lipid nature $[11,39]$. All other chemical shifts of about $\delta_{\mathrm{H}} 1.5-$ 2.5 correspond to aliphatic groups neighboring alkene and oxygen-containing groups such as alcohol, carbonyl, and ethers, which may be a consequence of lignin degradation products $[13,39]$.

In the oxygenated aliphatic region (around $\delta_{\mathrm{C}} / \delta_{\mathrm{H}} 50-$ $95 / 2.6-5.6 \mathrm{ppm})$, cross signals of methoxyl groups $\left(-\mathrm{OCH}_{3}\right.$, $\left.\delta_{\mathrm{C}} / \delta_{\mathrm{H}} 55.6 / 3.7 \mathrm{ppm}\right)$ and the different interunit linkages of wheat straw and olive tree pruning lignins were detected. Both spectra showed signals corresponding to $\beta-O-4^{\prime}$ substructures (A), being more prominent in the olive tree pruning residue. The $\mathrm{C}_{\alpha}-\mathrm{H}_{\alpha}$ correlations in $\beta-O-4^{\prime}$ substructures were observed in overlapping signals at $\delta_{\mathrm{C}} / \delta_{\mathrm{H}} 71.4 / 4.75$ and $72.3 / 4.86 \mathrm{ppm}$ for structures linked to $\mathrm{G}$ or $\mathrm{S}$ lignin units. Likewise, the $\mathrm{C}_{\beta}-\mathrm{H}_{\beta}$ correlations were found at $\delta_{\mathrm{C}} / \delta_{\mathrm{H}}$ 84.1/4.3 ppm for $\beta-O-4^{\prime} \mathrm{G}$ units and at $\delta_{\mathrm{C}} / \delta_{\mathrm{H}} 86.5 / 4.2 \mathrm{ppm}$
TABLE 2: Assignment of main lignin and sugars ${ }^{13} \mathrm{C}-{ }^{1} \mathrm{H}$ cross signals in the HSQC spectra of lignin-rich residues from wheat straw and olive tree pruning WIS fractions.

\begin{tabular}{|c|c|}
\hline$\delta_{\mathrm{C}} / \delta_{\mathrm{H}}(\mathrm{ppm})$ & Assignment \\
\hline $53.7 / 3.42$ & $\mathrm{C}_{\beta}-\mathrm{H}_{\beta}$ in phenylcoumaran substructures $(\mathbf{C})$ \\
\hline $54.1 / 3.04$ & $\mathrm{C}_{\beta}-\mathrm{H}_{\beta}$ in resinol substructures $(\mathbf{B})$ \\
\hline $55.6 / 3.7$ & $\mathrm{C}-\mathrm{H}$ in methoxyls $(\mathbf{M e O})$ \\
\hline $60.1 / 3.4-3.7$ & $\mathrm{C}_{\gamma}-\mathrm{H}_{\gamma}$ in $\beta-O-4^{\prime}$ substructures (A) \\
\hline $71.4 / 4.75$ & $\mathrm{C}_{\alpha}-\mathrm{H}_{\alpha}$ in $\beta-O-4^{\prime}$ linked to a $\mathbf{G}$ type unit (A) \\
\hline $70.9 / 3.77-4.14$ & $\mathrm{C}_{\gamma}-\mathrm{H}_{\gamma}$ in resinol substructures $(\mathbf{B})$ \\
\hline $72.3 / 4.86$ & $\mathrm{C}_{\alpha}-\mathrm{H}_{\alpha}$ in $\beta-O-4^{\prime}$ linked to an $\mathbf{S}$ type unit (A) \\
\hline $83.0 / 4.92$ & $\mathrm{C}_{\alpha}-\mathrm{H}_{\alpha}$ in spirodienone substructures $(\mathbf{D})$ \\
\hline $84.1 / 4.3$ & $\mathrm{C}_{\beta}-\mathrm{H}_{\beta}$ in $\beta-O-4^{\prime}$ linked to a $\mathbf{G}$ type unit $(\mathbf{A})$ \\
\hline $85.4 / 4.64$ & $\mathrm{C}_{\alpha}-\mathrm{H}_{\alpha}$ in resinol substructures $(\mathbf{B})$ \\
\hline $86.5 / 4.2$ & $\mathrm{C}_{\beta}-\mathrm{H}_{\beta}$ in $\beta-O-4^{\prime}$ linked to an $\mathrm{S}$ type unit (A) \\
\hline $87.4 / 5.4$ & $\mathrm{C}_{\alpha}-\mathrm{H}_{\alpha}$ in phenylcoumaran substructures $(\mathbf{C})$ \\
\hline $92.3 / 4.88$ & $\begin{array}{l}(1 \rightarrow 4) \text {-linked } \alpha \text {-D-Xylopyranosyl units } \\
\left(\boldsymbol{\alpha} \text {-D-X } \mathbf{X}^{\mathbf{R}}\right)\end{array}$ \\
\hline $97.0 / 4.2$ & $\begin{array}{l}(1 \rightarrow 4) \text {-linked } \beta \text {-D-Xylopyranosyl units } \\
\left(\boldsymbol{\beta} \text {-D-X } \mathbf{X}^{\mathbf{R}}\right)\end{array}$ \\
\hline $102.5 / 4.37$ & $\begin{array}{l}(1 \rightarrow 4) \text {-linked } \beta \text {-D-Xylopyranosyl units } \\
\left(\boldsymbol{\beta} \text {-D- } \mathbf{X}^{\mathbf{C} \mathbf{1} \mathbf{H} \mathbf{1}}\right)\end{array}$ \\
\hline $104.7 / 6.7$ & $\mathrm{C}_{2,6}-\mathrm{H}_{2,6}$ in $\mathrm{S}$ units $(\mathbf{S})$ \\
\hline 104.0/7.31 & $\mathrm{C}_{2^{\prime}}-\mathrm{H}_{2^{\prime}}$ and $\mathrm{C}_{6^{\prime}}-\mathrm{H}_{6^{\prime}}$ in tricin $(\mathrm{T})$ \\
\hline $106.7 / 7.2$ & $\mathrm{C}_{2,6}-\mathrm{H}_{2,6}$ in oxidized $\left(\mathrm{C}_{\alpha}=\mathrm{O}\right) \mathrm{S}$ units $\left(\mathbf{S}^{\prime}\right)$ \\
\hline 111.0/6.99 & $\mathrm{C}_{2}-\mathrm{H}_{2}$ in $\mathrm{G}$ units $(\mathbf{G})$ \\
\hline $111.0 / 7.32$ & $\mathrm{C}_{2}-\mathrm{H}_{2}$ in ferulate $(\mathbf{F A})$ \\
\hline $113.5 / 6.27$ & $\mathrm{C}_{\beta}-\mathrm{H}_{\beta}$ in $p$-coumarate $(\mathbf{P C A})$ and ferulate $(\mathbf{F A})$ \\
\hline $115.2 / 6.7-6.9$ & $\mathrm{C}_{5}-\mathrm{H}_{5}$ in $\mathrm{G}$ units $(\mathbf{G})$ \\
\hline $115.2 / 6.74$ & $\mathrm{C}_{3,5}-\mathrm{H}_{3,5}$ in $p$-hydroxyphenyl $(\mathbf{H})$ \\
\hline $115.4 / 6.79$ & $\mathrm{C}_{3}-\mathrm{H}_{3}$ and $\mathrm{C}_{5}-\mathrm{H}_{5}$ in $p$-coumarate (PCA) \\
\hline $119.6 / 6.81$ & $\mathrm{C}_{6}-\mathrm{H}_{6}$ in $\mathrm{G}$ units $(\mathbf{G})$ \\
\hline $123.2 / 7.15$ & $\mathrm{C}_{6}-\mathrm{H}_{6}$ in ferulate $(\mathbf{F A})$ \\
\hline $128 / 7.17$ & $\mathrm{C}_{2,6}-\mathrm{H}_{2,6}$ in $p$-hydroxyphenyl $(\mathbf{H})$ \\
\hline $129.8 / 7.51$ & $\mathrm{C}_{2}-\mathrm{H}_{2}$ and $\mathrm{C}_{6}-\mathrm{H}_{6}$ in $p$-coumarate $($ PCA) \\
\hline $143.8 / 7.49$ & $\mathrm{C}_{\alpha}-\mathrm{H}_{\alpha}$ in $p$-coumarate (PCA) and ferulate (FA) \\
\hline
\end{tabular}

for $\beta-O-4^{\prime} \mathrm{S}$ units. The $\mathrm{C}_{\gamma}-\mathrm{H}_{\gamma}$ correlations in $\beta-O-4^{\prime}$ substructures were observed at $\delta_{\mathrm{C}} / \delta_{\mathrm{H}} 60.1 / 3.4$ and $3.7 \mathrm{ppm}$, partially overlapped with other signals. Strong signals for resinol $\left(\beta-\beta^{\prime}\right)$ substructures (B) were also detected in the spectrum of olive tree pruning, with their $\mathrm{C}_{\alpha}-\mathrm{H}_{\alpha}, \mathrm{C}_{\beta}-\mathrm{H}_{\beta}$, and the double $\mathrm{C}_{\gamma}-\mathrm{H}_{\gamma}$ correlations at $\delta_{\mathrm{C}} / \delta_{\mathrm{H}} 85.4 / 4.64,54.1 / 3.04$, and $70.9 / 3.77$ and $4.14 \mathrm{ppm}$ (i.e., the two diastereotopic protons attached to the $\gamma$ carbon are well separated). By contrast, the signals for resinol substructures showed very low proportions in wheat straw. Phenylcoumaran $\left(\beta-5^{\prime}\right)$ substructures $(C)$ were also clearly found in both spectra, the signals for their $\mathrm{C}_{\alpha}-\mathrm{H}_{\alpha}$ and $\mathrm{C}_{\beta}-\mathrm{H}_{\beta}$ correlations being observed at $\delta_{\mathrm{C}} / \delta_{\mathrm{H}}$ $87.4 / 5.4$ and $53.7 / 3.42 \mathrm{ppm}$, although with lower intensities in olive tree pruning. Finally, weak signals corresponding to spirodienone substructures (D) were also observed in 


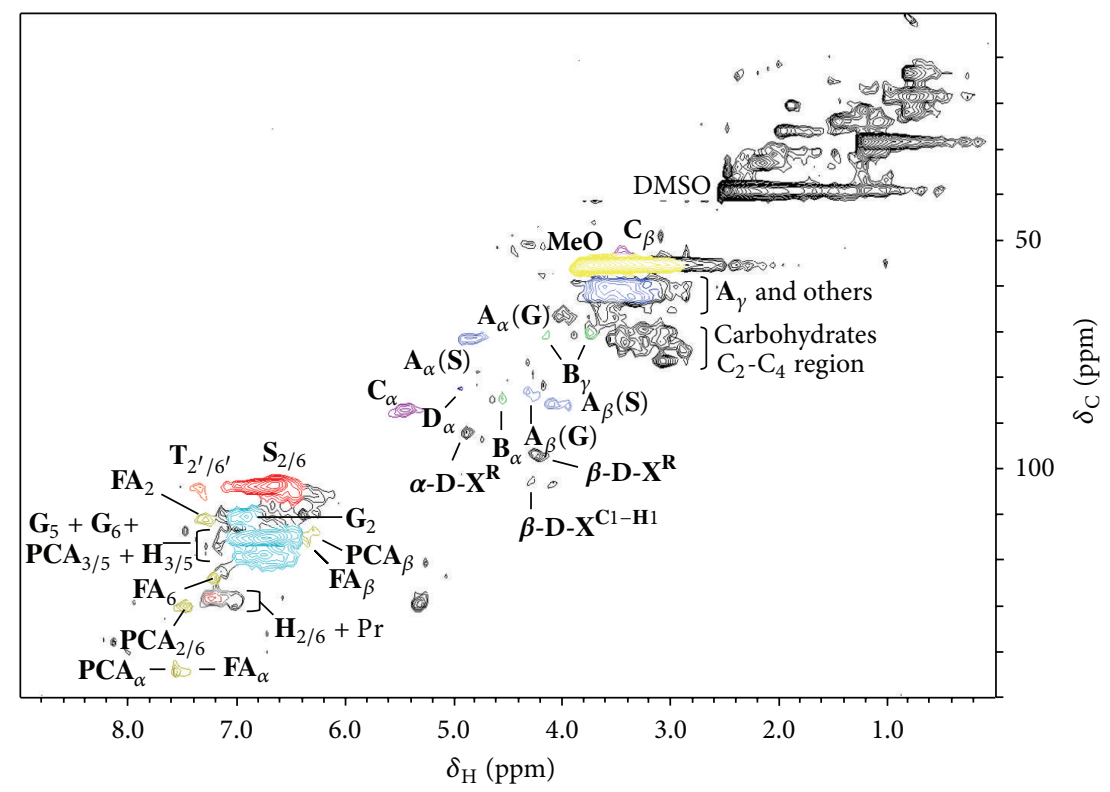

(a)



(b)

FIGURE 2: HSQC 2D-NMR spectra, $\delta_{\mathrm{C}} / \delta_{\mathrm{H}} 0-150 / 0-9 \mathrm{ppm}$ region, of the lignin-rich residues from wheat straw (a) and olive tree pruning (b) WIS fractions. The aliphatic, oxygenated aliphatic, and aromatic region are observed. Cross signals of the residual DMSO and protein residue $(\mathrm{Pr})$ are indicated.

the wheat straw spectrum, its $\mathrm{C}_{\alpha}-\mathrm{H}_{\alpha}$ correlation being observed at $\delta_{\mathrm{C}} / \delta_{\mathrm{H}} 83.0 / 4.92 \mathrm{ppm}$.

Regarding the carbohydrates, the remaining sugars content was reflected in a set of unidentified cross signals in the $\delta_{\mathrm{C}} / \delta_{\mathrm{H}} 67-75 / 3.0-3.8 \mathrm{ppm}$ region that could correspond to hexose units, being more visible in the wheat straw spectrum. In addition, the reducing ends of $(1 \rightarrow 4) \alpha$-D-Xylopyranosyl units $\left(\alpha\right.$-D-X $\left.\mathrm{X}^{\mathrm{R}}\right)$ and $(1 \rightarrow 4) \beta$-D-Xylopyranosyl units $(\beta$-D$\mathrm{X}^{\mathrm{R}}$ ) were also presented at $\delta_{\mathrm{C}} / \delta_{\mathrm{H}} 92.3 / 4.88$ and $97.0 / 4.2 \mathrm{ppm}$, respectively; and the $\mathrm{C}_{1}-\mathrm{H}_{1}$ cross signal of $(1 \rightarrow 4)$
$\beta$-D-Xylopyranosyl units $\left(\beta-\mathrm{D}-\mathrm{X}^{\mathrm{C}_{1}-\mathrm{H}_{1}}\right)$ was presented at $\delta_{\mathrm{C}} / \delta_{\mathrm{H}} 102.5 / 4.37 \mathrm{ppm}$. By contrast, many of these signals assigned to xylan units were not found in olive tree pruning residue.

The main cross signals in the aromatic region (around $\left.\delta_{\mathrm{C}} / \delta_{\mathrm{H}} 95-150 / 5.6-9.0 \mathrm{ppm}\right)$ of both spectra corresponded to the aromatic rings of the different $S$ and $G$ lignin units. The $S$ lignin units showed a prominent signal for the $\mathrm{C}_{2,6}-\mathrm{H}_{2,6}$ correlation at $\delta_{\mathrm{C}} / \delta_{\mathrm{H}} 104.7 / 6.7 \mathrm{ppm}$. In addition, signals corresponding to $\mathrm{C}_{2,6}-\mathrm{H}_{2,6}$ correlations at $\delta_{\mathrm{C}} / \delta_{\mathrm{H}} 106.7 / 7.2 \mathrm{ppm}$ 
<smiles>COc1cc(C(O)C(CO)Oc2c(OC)cc(C(=O)O)cc2OC)cc(OC)c1OC</smiles>

A

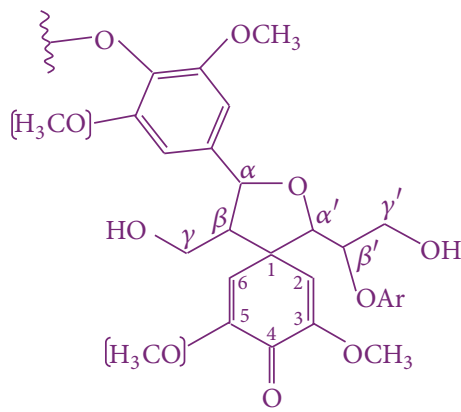

D

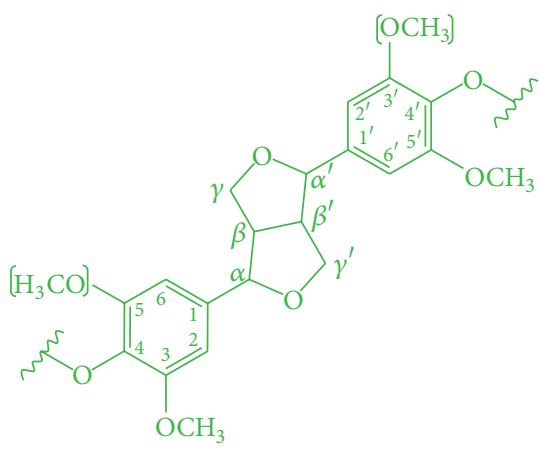

B

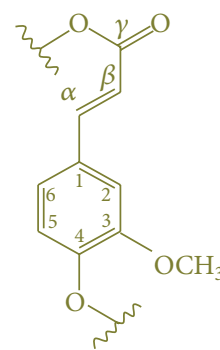

FA

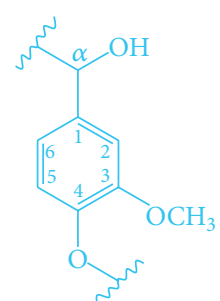

G<smiles>COc1cc(C(C)=O)cc(OC)c1OC</smiles>

$\mathbf{S}^{\prime}$<smiles>COc1cc(C(C(=O)O)C(=O)c2cc(N)cc(OC)c2OC)cc(OC)c1OC</smiles>

C<smiles>CCOc1ccc(C(C)O)cc1</smiles><smiles>CCOC(=O)C=Cc1ccc(OC)cc1</smiles>

H

PCA<smiles>COc1cc(C(C)O)cc(OC)c1OC</smiles>

$S$<smiles>COc1cc(-c2cc(=O)c3c(O)cc(O)cc3o2)cc(OC)c1OC</smiles>

$\mathbf{T}$<smiles>[Z]COC1OC([R])C([NH+]([O-])[O-])C(O)C1O</smiles>

$\mathbf{X}$

FIGURE 3: Main lignin and carbohydrate structures identified in the lignin-rich residues from wheat straw and olive tree pruning WIS fractions: A, $\beta-O-4^{\prime} ; \mathbf{B}$, resinols with $\beta-\beta^{\prime}, \alpha-O-\gamma^{\prime}$, and $\gamma-O-\alpha^{\prime}$ linkages; $\mathbf{C}$, phenylcoumarans with $\alpha-O-4^{\prime}$ and $\beta-5^{\prime}$ linkages; $\mathbf{D}$, spirodienones with $\beta-1^{\prime}, \alpha$-O-4' linkages; FA, ferulic acid; G, guaiacyl unit; $\mathbf{H}, p$-hydroxyphenyl unit; PCA, $p$-coumaric acid; $\mathbf{S}$, syringyl unit; $\mathbf{S}^{\prime}$, oxidized syringyl units with a $\mathrm{C}_{\alpha}$ ketone; $\mathbf{T}$, tricin end unit; $\mathbf{X}$, xylopyranose $(\mathrm{R}, \mathrm{OH})$.

in $\mathrm{C}_{\alpha}$ oxidized $\mathrm{S}$ units were only present in the olive tree pruning spectrum. It has been identified as $\mathrm{C}_{\alpha}$ ketone by HMBC (heteronuclear multiple bond correlation) 2D-NMR experiments [40]. The G lignin units showed different correlations for $\mathrm{C}_{2}-\mathrm{H}_{2}\left(\delta_{\mathrm{C}} / \delta_{\mathrm{H}} 111.0 / 6.99 \mathrm{ppm}\right)$ and $\mathrm{C}_{5}-\mathrm{H}_{5} / \mathrm{C}_{6}-$ $\mathrm{H}_{6}\left(\delta_{\mathrm{C}} / \delta_{\mathrm{H}} 115.2 / 6.7\right.$ and $6.9 \mathrm{ppm}$ and $\left.\delta_{\mathrm{C}} / \delta_{\mathrm{H}} 119.6 / 6.81 \mathrm{ppm}\right)$. Signals corresponding to $\mathrm{C}_{3,5}-\mathrm{H}_{3,5}$ and $\mathrm{C}_{2,6}-\mathrm{H}_{2,6}$ correlations in $\mathrm{H}$ lignin units were also observed at $\delta_{\mathrm{C}} / \delta_{\mathrm{H}} 115.2 / 6.74$ and $\delta_{\mathrm{C}} / \delta_{\mathrm{H}} 128 / 7.17 \mathrm{ppm}$, respectively. Nevertheless, the signal corresponding to $\mathrm{C}_{2,6}-\mathrm{H}_{2,6}$ was partially overlapped in both spectra by the cross signals at $\delta_{\mathrm{C}} / \delta_{\mathrm{H}} 128.5 / 7.24$ and 130.1/7.03 from protein impurities [41], hindering $\mathrm{H}$ lignin analysis.
As is typical in spectra from wheat straw and other grasses $[5,27,42]$, wheat straw lignin showed prominent signals corresponding to $p$-coumarate (PCA) and ferulate (FA) substructures. Cross signals corresponding to the $\mathrm{C}_{2,6}-\mathrm{H}_{2,6}$ at $\delta_{\mathrm{C}} / \delta_{\mathrm{H}} 129.8 / 7.51 \mathrm{ppm}$ and $\mathrm{C}_{3,5}-\mathrm{H}_{3,5}$ at $\delta_{\mathrm{C}} / \delta_{\mathrm{H}} 115.4 / 6.79 \mathrm{ppm}$ correlations of the aromatic ring and signals for the correlations of the unsaturated $\mathrm{C}_{\alpha}-\mathrm{H}_{\alpha}$ at $\delta_{\mathrm{C}} / \delta_{\mathrm{H}} 143.8 / 7.49 \mathrm{ppm}$ and $\mathrm{C}_{\beta}-\mathrm{H}_{\beta}$ at $\delta_{\mathrm{C}} / \delta_{\mathrm{H}} 113.5 / 6.27 \mathrm{ppm}$ of the $p$-coumarates were observed. Signals corresponding to the $\mathrm{C}_{2}-\mathrm{H}_{2}$ and $\mathrm{C}_{6}-\mathrm{H}_{6}$ correlations of ferulate substructures were also observed at $\delta_{\mathrm{C}} / \delta_{\mathrm{H}} 111.0 / 7.32$ and $123.3 / 7.15 \mathrm{ppm}$, respectively. The correlations corresponding to the unsaturated $\mathrm{C}_{\alpha}-\mathrm{H}_{\alpha}$ and $\mathrm{C}_{\beta}-\mathrm{H}_{\beta}$ 
TABLE 3: Structural characteristic of lignin (main interunit linkages, aromatic units, $\mathrm{S} / \mathrm{G}$ ratio, $p$-hydroxycinnamate content, and $p$ coumarate/ferulate ratio) from integration of ${ }^{13} \mathrm{C}-{ }^{1} \mathrm{H}$ correlation peaks in the HSQC spectra of the fermentation residues from wheat straw and olive tree pruning WIS fractions.

\begin{tabular}{lcc}
\hline & Wheat straw & Olive tree pruning \\
\hline Lignin interunit linkages & & \\
$\beta-O-4^{\prime}$ (A) & 50 & 65 \\
Resinols (B) & 15 & 25 \\
Phenylcoumarans (C) & 32 & 10 \\
Spirodienones (D) & 3 & - \\
Lignin aromatic units & & \\
H & 3 & 1 \\
G & 60 & 16 \\
S & 37 & 83 \\
S/G ratio & 0.6 & 5.2 \\
$p$-Hydroxycinnamates & & - \\
p-Coumarates (PCA) & 4.3 & - \\
Ferulates (FA) & 2.7 & - \\
PCA/FA ratio & 1.6 & \\
\hline
\end{tabular}

overlapped with those of the $p$-coumarates. Previous studies in wheat straw lignin have indicated that $p$-coumarates and acetates are esterified to the lignin side chain $[5,32]$, acylating the $\gamma-\mathrm{OH}$ of the lignin side chain as established for other grasses [24, 43]. Indeed, DFRC (derivatization followed by reductive cleavage) analysis of wheat straw lignin has showed that $p$-coumarates acylate the $\gamma-\mathrm{OH}$ in structures other than $\beta$-ethers, whereas acetates acylate the $\gamma-\mathrm{OH}$ in $\beta-O-4^{\prime}$ aryl ether substructures [5]. However, the oxygenated aliphatic region of wheat straw spectrum did not show the cross signals $\left(\delta_{\mathrm{C}} / \delta_{\mathrm{H}} 63.5 / 3.8\right.$ and $\left.4.3 \mathrm{ppm}\right)$ corresponding to the $\mathrm{C}_{\gamma}-\mathrm{H}_{\gamma}$ correlations of $\gamma$-acylated $\beta-O-4^{\prime}$ substructures with $p$-coumarates and acetates [5]. Ferulates, on the other hand, are mostly linked to lignin by ether bonds $[5,32]$, mainly at the $\alpha$-and $\beta$-carbons contributing to lignin-carbohydrate bridges [43].

Finally, a cross signal at $\delta_{\mathrm{C}} / \delta_{\mathrm{H}} 104.0 / 7.31 \mathrm{ppm}$ in the wheat straw spectra corresponded to aromatic $\mathrm{C}_{2^{\prime}, 6^{\prime}}-\mathrm{H}_{2^{\prime}, 6^{\prime}}$ of tricin (T, 5,7,4'-trihydroxy- $3^{\prime}-5^{\prime}$-dimethoxyflavone). As is well known, tricin is widely distributed in grasses, including wheat, rice, barley, sorghum, and maize [44]. Tricin skeleton can be linked to a phenylpropanoid moiety through a $\beta-O-4^{\prime}$ bond, which may be incorporated into lignification of plants, acting as lignin monomers [5].

\subsection{D-NMR Spectral Analysis: Semiquantitative 2D-NMR.} The relative abundances of the main interunit linkages and the molar abundances of the different lignin units $(\mathrm{H}, \mathrm{G}$, and S), $p$-coumarates, and ferulates, as well as the molar S/G ratios of the wheat straw and olive tree pruning, estimated from volume integration of contours in the HSQC spectra [33], are shown in Table 3.

It is well accepted in the literature that under steam explosion pretreatment conditions $\beta-O-4^{\prime}$ bonds are degraded by the organic acids formed from the acetylated lignocellulose components $[30-32,34,35,39,45,46]$. As explained previously, steam explosion pretreatment is an autohydrolytic process catalyzed by the organic acids formed from the acetylated lignocellulose components. During the steam explosion, the steam cleaves the labile xylans acetyls (2-OAc- $\beta$-D-X and 3-O-Ac- $\beta$-D-X) and 4-O-methyl glucuronic acid (4-O-MeGlcA), thus releasing acetic acid and uronic acid. Even the subsequent enzymatic hydrolysis of the steam pretreated material again cleaves acetates via a different mechanism compared to the steam explosion pretreatment [32]. Then, the organic acids released lead to acid catalyzed hydrolysis (acidolysis) of glycosidic bonds in hemicelluloses and of $\beta-O-4^{\prime}$ linkages in lignin $[34,35]$. In spite of $\beta-O-$ $4^{\prime}$ bond degradation during steam explosion reported in the literature, the semiquantitative HSQC spectrum results of wheat straw lignin demonstrated a relatively high content of $\beta-O-4^{\prime}$ aryl ether linkages (50\%), together with minor amounts of $\beta-5^{\prime}$ phenylcoumarans (32\%), $\beta-\beta^{\prime}$ resinols (15\%), and spirodienones $(3 \%)$. On these latter substructures, the literature has described contradictory results during the bioethanol production process. Yelle et al. [32] observed that phenylcoumarans and resinols withstand the steam explosion and subsequent enzymatic hydrolysis of wheat straw. By contrast, Rahikainen et al. [45] and Heikkinen et al. [46] described an increase in the level of $\beta-5^{\prime}$ interunit linkages after the steam explosion treatment of wheat straw. This increment was explained as a possible rearrangement between interunit linkages, starting with the homolytic cleavage of the $\beta-O-4^{\prime}$, and followed by the formation of the new $\beta$ $5^{\prime}$ linkages [47]. Finally, other studies have showed the degradation of resinol and phenylcoumaran linkages during the steam pretreatment of poplar wood and switchgrass [30, 31].

In agreement with the above FTIR analysis, the wheat straw lignin was dominated by $\mathrm{G}$ lignin units (60\%) followed by $\mathrm{S}(37 \%)$ and $\mathrm{H}$ units $(3 \%)$, resulting in a $\mathrm{S} / \mathrm{G}$ ratio of 0.5 . In addition, the abundance of $p$-coumarates $(4.3 \%)$ was higher than that of ferulates $(2.7 \%)$, showing a PCA/FA ratio of 1.6. Different changes in the lignin aromatics and $p$-hydroxycinnamates during the bioethanol production has been also described in the literature. Yelle et al. [32] have suggested that the steam explosion of wheat straw does not change the $p$-hydroxyphenyl/guaiacyl/syringyl distribution and hydroxycinnamates to any significant degree. Nevertheless, these authors observed some deacylation of $p$ coumarates, a phenomenon that could support the absence of the cross signals $\left(\delta_{\mathrm{C}} / \delta_{\mathrm{H}} 63.5 / 3.8\right.$ and $\left.4.3 \mathrm{ppm}\right)$ corresponding to the $\mathrm{C}_{\gamma}-\mathrm{H}_{\gamma}$ correlations of $\gamma$-acylated $\beta-O-4^{\prime}$ substructures with $p$-coumarates in the wheat straw lignin residue spectrum (Figure 2(a)). By contrast, Rahikainen et al. [45] and Heikkinen et al. [46] described a substantial decrease of S/G ratio and hydroxycinnamates after the steam explosion treatment of wheat straw. In the same way, other studies have reported the same effects during the steam pretreatment of poplar and switchgrass [30, 31].

Regarding olive tree pruning, the residual lignin also displayed a predominance of $\beta-O-4^{\prime}$ aryl ether linkages $(65 \%)$, followed by $\beta-\beta^{\prime}$ resinols $(25 \%)$ and $\beta-5^{\prime}$ phenylcoumarans (10\%). Despite the higher severity factor $\log \left(R_{o}\right)$ of steam 
explosion pretreatment on olive tree pruning (4.82), compared to wheat straw (4.23), olive tree pruning lignin showed less degradation than that of wheat straw, as revealed by the higher intensities of lignin side chain signals, especially $\beta$ $O-4^{\prime}$ and resinol substructures (Figure 2(b)). However, more severe carbohydrate dissolution, particularly hemicelluloses, was observed. This effect was already reported by Yelle et al. [32], who described a more dramatic effect on wheat straw lignin at lower pretreatment conditions (steam pretreatment with a severity factor $\log \left(R_{o}\right)$ of 3.57) than that observed on aspen lignin at higher pretreatment conditions (steam explosion with a severity factor $\log \left(R_{o}\right)$ of 3.79). One possible reason proposed for this phenomenon is the presence of more latent acid groups (i.e., more acylation by acetate, ferulate, and $p$-coumarate) in wheat straw compared to aspen wood and olive tree pruning in this study, which help catalyze acidolysis of lignin side chains [32]. With regard to the aromatic region of olive tree pruning lignin, the $S / G$ ratio calculated by $2 \mathrm{D}-\mathrm{NMR}$ (5.2), similar to that estimated by FTIR (5.1), was significantly greater than that of wheat straw lignin (0.5), with a lower proportion of $\mathrm{H}$ units (1\%).

\subsection{Application Potential of Residual Lignins in Respect to} Their Characteristics: General Comments. Potential valueadded products from industrial lignins include their use as macromolecule in lignin-based materials and the production of low molecular weight chemicals [7]. These applications will be determined by the structural features of lignin, which are different depending on raw material and industrial procedure. Thus, the residual lignins from bioethanol production of wheat straw and olive tree pruning clearly show a higher abundance of native $\beta-O-4^{\prime}$ aryl ether linkages compared to the traditional industrial lignins such as kraft and soda-AQ lignins $[13,37,48]$. Consequently, the phenolic content of these bioethanol residual lignins would be significantly lower than that of traditional lignins. This feature makes residual lignins from bioethanol unsuitable for resin applications (e.g., phenol-formaldehyde resins), a field where the phenolic units of lignin are key functional groups for its reactivity [16]. By contrast, the high content of $\beta-O-4^{\prime}$ linkages would result in a higher molecular mass lignin. The high molecular weight could be an advantage in lignin-based dispersants providing better sorption properties [37]. Moreover, high molecular weight lignin could also be beneficial in respect of mechanical properties of lignin-based composites [37].

Regarding lignin as source for aromatic chemicals, different approaches have been reported for its conversion into low molecular weight chemicals, including thermochemical treatments, catalytic technology, and biotechnological depolymerization [7, 37]. Lignin with a predominance of syringyl units is more favorable for thermal or catalytic fragmentation because methoxy substituents in ortho-positions of the aromatic ring minimize the presence of carboncarbon linkages [7]. Thus, the residual lignin from olive tree pruning, with a higher $\mathrm{S}$ lignin content compared to wheat straw, would be more reactive to thermal and chemical depolymerization.

\section{Conclusion}

The lignin-rich residues from bioethanol production of wheat straw and olive tree pruning WIS fractions were characterized by FTIR and 2D-NMR. According to the chemical composition, both techniques confirmed the high lignin content of both residues with some sugars and protein impurities. Wheat straw showed a typical lignin with a low S/G ratio, a certain proportion of $\mathrm{H}$ units, and the presence of $p$ hydroxycinnamates, whereas a strong predominance of $S$ over $G$ units was observed for olive tree pruning lignin. A high content of $\beta-O-4^{\prime}$ aryl ether linkages, followed by resinols and phenylcoumarans, was found in both residual lignins. The high content of native aryl ether linkages in both lignins would result in a high molecular mass lignin. Based on this, the lignins studied herein could be beneficial as macromolecules for dispersants and composites. In addition, low molecular weight chemicals could also be produced from residual lignins, with olive tree pruning lignin being potentially more reactive to depolymerization reactions. Nevertheless, these hypothetical target applications, that is, lignin as macromolecule and lignin-aromatic chemicals, need to be verified with the actual testing.

\section{Conflict of Interests}

The authors declare that there is no conflict of interests regarding the publication of this paper.

\section{Acknowledgments}

The authors wish to thank the Spanish MIMECO for funding this study via Projects CTQ 2011-28503-C02-01, ENE201129112-C02-01, and CTQ2013-47158-R. The standard mixture of Celluclast 1.5L and Novozyme 188 was kindly provided by Novozymes (Denmark). Fermentis (France) is acknowledged for kindly providing the strain $S$. cerevisiae Ethanol Red. Salvador Sastre (INIA-CIFOR) is greatly acknowledged for determining the total nitrogen content of lignin-rich residues.

\section{References}

[1] Directive 2009/28/EC, Directive of the European Parliament and of the Council of 23 April 2009 on the Promotion and the Use of Energy from Renewable Sources, European Union, Brussels, Belgium, 2009, http://eur-lex.europa.eu/legal-content/EN/TXT/ $\mathrm{PDF} /$ ?uri=CELEX:32009L0028\&from=EN.

[2] I. Ballesteros, M. J. Negro, J. M. Oliva, A. Cabañas, P. Manzanares, and M. Ballesteros, "Ethanol production from steamexplosion pretreated wheat straw," Applied Biochemistry and Biotechnology, vol. 130, no. 1-3, pp. 496-508, 2006.

[3] C. Cara, E. Ruiz, M. Ballesteros, P. Manzanares, M. J. Negro, and E. Castro, "Production of fuel ethanol from steam-explosion pretreated olive tree pruning," Fuel, vol. 87, no. 6, pp. 692-700, 2008.

[4] E. Tomás-Pejó, J. M. Oliva, and M. Ballesteros, "Realistic approach for full-scale bioethanol production from lignocellulose: a review," Journal of Scientific and Industrial Research, vol. 67, no. 11, pp. 874-884, 2008. 
[5] J. C. del Río, J. Rencoret, P. Prinsen, Á. T. Martínez, J. Ralph, and A. Gutiérrez, "Structural characterization of wheat straw lignin as revealed by analytical pyrolysis, $2 \mathrm{D}-\mathrm{NMR}$, and reductive cleavage methods," Journal of Agricultural and Food Chemistry, vol. 60, no. 23, pp. 5922-5935, 2012.

[6] P. Sannigrahi and A. J. Ragauskas, "Characterization of fermentation residues from the production of bio-ethanol from lignocellulosic feedstocks," Journal of Biobased Materials and Bioenergy, vol. 5, no. 4, pp. 514-519, 2011.

[7] A. J. Ragauskas, G. T. Beckham, M. J. Biddy et al., "Lignin valorization: improving lignin processing in the biorefinery," Science, vol. 344, no. 6185, Article ID 1246843, pp. 1-10, 2014.

[8] Á. T. Martínez, F. J. Ruiz-Dueñas, M. J. Martínez, J. C. del Río, and A. Gutiérrez, "Enzymatic delignification of plant cell wall: from nature to mill," Current Opinion in Biotechnology, vol. 20, no. 3, pp. 348-357, 2009.

[9] O. Faix, "Classification of lignins from different botanical origins by FT-IR spectroscopy," Holzforschung, vol. 45, no. s1, pp. 21-28, 1991.

[10] J. Ralph, J. M. Marita, S. A. Ralph et al., "Solution-state NMR of lignin," in Advances in Lignocellulosics Characterization, D. S. Argyropoulos, Ed., pp. 55-108, Tappi Press, Atlanta, Ga, USA, 1999.

[11] M. Y. Balakshin, E. A. Capanema, L. Chen, and H. S. Gracz, "Elucidation of the structures of residual and dissolved pine kraft lignins using an HMQC NMR technique," Journal of Agricultural and Food Chemistry, vol. 51, no. 21, pp. 6116-6127, 2003.

[12] E. A. Capanema, M. Y. Balakshin, C.-L. Chen, J. S. Gratzl, and H. Gracz, "Structural analysis of residual and technical lignins by ${ }^{1} \mathrm{H}_{-}{ }^{13} \mathrm{C}$ correlation $2 \mathrm{D}$ NMR-spectroscopy," Holzforschung, vol. 55 , no. 3, pp. 302-308, 2001.

[13] C. Fernández-Costas, S. Gouveia, M. A. Sanromán, and D. Moldes, "Structural characterization of Kraft lignins from different spent cooking liquors by $1 \mathrm{D}$ and 2D Nuclear Magnetic Resonance Spectroscopy," Biomass and Bioenergy, vol. 63, pp. 156-166, 2014.

[14] D. Ibarra, M. I. Chávez, J. Rencoret et al., "Lignin modification during Eucalyptus globulus kraft pulping followed by totally chlorine-free bleaching: a two-dimensional nuclear magnetic resonance, Fourier transform infrared, and pyrolysis-gas chromatography/mass spectrometry study," Journal of Agricultural and Food Chemistry, vol. 55, no. 9, pp. 3477-3490, 2007.

[15] T. M. Liitiä, S. L. Maunu, B. Hortling, M. Toikka, and I. Kilpeläinen, "Analysis of technical lignins by two- and threedimensional NMR spectroscopy," Journal of Agricultural and Food Chemistry, vol. 51, no. 8, pp. 2136-2143, 2003.

[16] A. Tejado, C. Peña, J. Labidi, J. M. Echeverria, and I. Mondragon, "Physico-chemical characterization of lignins from different sources for use in phenol-formaldehyde resin synthesis," Bioresource Technology, vol. 98, no. 8, pp. 1655-1663, 2007.

[17] M. Ambye-Jensen, S. T. Thomsen, Z. Kádár, and A. S. Meyer, "Ensiling of wheat straw decreases the required temperature in hydrothermal pretreatment," Biotechnology for Biofuels, vol. 6, no. 1, article 116, 2013.

[18] M. Ballesteros, J. M. Oliva, M. J. Negro, P. Manzanares, and I. Ballesteros, "Ethanol from lignocellulosic materials by a simultaneous saccharification and fermentation process (SFS) with Kluyveromyces marxianus CECT 10875," Process Biochemistry, vol. 39, no. 12, pp. 1843-1848, 2004.

[19] S. J. Horn, Q. D. Nguyen, B. Westereng, P. J. Nilsen, and V. G. H. Eijsink, "Screening of steam explosion conditions for glucose production from non-impregnated wheat straw," Biomass and Bioenergy, vol. 35, no. 12, pp. 4879-4886, 2011.

[20] T. K. Ghose, "Measurement of cellulase activities," Pure and Applied Chemistry, vol. 59, no. 2, pp. 257-268, 1987.

[21] "NREL, Chemical Analysis and Testing Laboratory Analytical Procedures, National Renewable Energy Laboratory, Golden, Colo, USA," 2007.

[22] J. Kjeldahl, "A new method for the determination of nitrogen in organic matter," Journal of Analytical Chemistry, vol. 22, pp. 366-382, 1883.

[23] D. Ibarra, J. C. del Río, A. Gutiérrez et al., "Isolation of highpurity residual lignins from eucalypt paper pulps by cellulase and proteinase treatments followed by solvent extraction," Enzyme and Microbial Technology, vol. 35, no. 2-3, pp. 173-181, 2004.

[24] A. Toledano, X. Erdocia, L. Serrano, and J. Labidi, "Influence of extraction treatment on olive tree (Olea europaea) pruning lignin structure," Environmental Progress and Sustainable Energy, vol. 32, no. 4, pp. 1187-1194, 2013.

[25] J. C. del Río, A. Gutiérrez, I. M. Rodríguez, D. Ibarra, and Á. T. Martínez, "Composition of non-woody plant lignins and cinnamic acids by Py-GC/MS, Py/TMAH and FT-IR," Journal of Analytical and Applied Pyrolysis, vol. 79, no. 1-2, pp. 39-46, 2007.

[26] R. Bechtold, A. E. González, G. Almendros, M. J. Martínez, and A. T. Martínez, "Lignin alteration by Ganoderma australe and other white-rot fungi after solid-state fermentation of beech wood," Holzforschung, vol. 47, no. 2, pp. 91-96, 1993.

[27] J. C. del Río, J. Rencoret, G. Marques et al., "Highly acylated (acetylated and/or p-coumaroylated) native lignins from diverse herbaceous plants," Journal of Agricultural and Food Chemistry, vol. 56, no. 20, pp. 9525-9534, 2008.

[28] S. A. Ralph, J. Ralph, and L. Landucci, NMR Database of Lignin and Cell Wall Model Compounds, US Forest Products Laboratory, Madison, Wis, USA, 2004, http://ars.usda.gov/ Services/docs.htm?docids10491.

[29] J. Ralph and L. L. Landucci, "NMR of lignins," in Lignin and Lignans, C. Heitner, D. R. Dimmel, and J. A. Schmidt, Eds., Advances in Chemistry, chapter 5, pp. 137-243, CRC Press, New York, NY, USA, 2010.

[30] R. Samuel, M. Foston, N. Jaing et al., "HSQC (heteronuclear single quantum coherence $)^{13} \mathrm{C}-{ }^{1} \mathrm{H}$ correlation spectra of whole biomass in perdeuterated pyridinium chloride-DMSO system: an effective tool for evaluating pretreatment," Fuel, vol. 90, no. 9, pp. 2836-2842, 2011.

[31] R. Samuel, M. Foston, N. Jiang, L. Allison, and A. J. Ragauskas, "Structural changes in switchgrass lignin and hemicelluloses during pretreatments by NMR analysis," Polymer Degradation and Stability, vol. 96, no. 11, pp. 2002-2009, 2011.

[32] D. J. Yelle, P. Kaparaju, C. G. Hunt et al., "Two-dimensional NMR evidence for cleavage or lignin and xylan substituents in wheat straw through hydrothermal pretreatment and enzymatic hydrolysis," Bioenergy Research, vol. 6, no. 1, pp. 211-221, 2013.

[33] J.-L. Wen, S.-L. Sun, B.-L. Xue, and R.-C. Sun, "Recent advances in characterization of lignin polymer by solution-state nuclear magnetic resonance (NMR) methodology," Materials, vol. 6, no. 1, pp. 359-391, 2013.

[34] P. Alvira, E. Tomás-Pejó, M. Ballesteros, and M. J. Negro, "Pretreatment technologies for an efficient bioethanol production process based on enzymatic hydrolysis: a review," Bioresource Technology, vol. 101, no. 13, pp. 4851-4861, 2010. 
[35] J. Li, G. Henriksson, and G. Gellerstedt, "Lignin depolymerization/repolymerization and its critical role for delignification of aspen wood by steam explosion," Bioresource Technology, vol. 98, no. 16, pp. 3061-3068, 2007.

[36] I. Ballesteros, M. Ballesteros, C. Cara et al., "Effect of water extraction on sugars recovery from steam exploded olive tree pruning," Bioresource Technology, vol. 102, no. 11, pp. 6611-6616, 2011.

[37] A. Vishtal and A. Kraslawski, "Challenges in industrial applications of technical lignins," BioResources, vol. 6, no. 3, pp. 35473568, 2011.

[38] A. M. da Costa Lopes, K. G. João, D. F. Rubik et al., "Pretreatment of lignocellulosic biomass using ionic liquids: wheat straw fractionation," Bioresource Technology, vol. 142, pp. 198208, 2013.

[39] R. Martin-Sampedro, E. A. Capanema, I. Hoeger, J. C. Villar, and O. J. Rojas, "Lignin changes after steam explosion and laccase-mediator treatment of eucalyptus wood chips," Journal of Agricultural and Food Chemistry, vol. 59, no. 16, pp. 87618769, 2011.

[40] D. Ibarra, M. I. Chávez, J. Rencoret et al., "Structural modification of eucalypt pulp lignin in a totally chlorine-free bleaching sequence including a laccase-mediator stage," Holzforschung, vol. 61, no. 6, pp. 634-646, 2007.

[41] C.-L. Chen, E. A. Capanema, and H. S. Gracz, "Comparative studies on the delignification of pine kraft-anthraquinone pulp with hydrogen peroxide by binucleus $\mathrm{Mn}(\mathrm{IV})$ complex catalysis," Journal of Agricultural and Food Chemistry, vol. 51, no. 21, pp. 6223-6232, 2003.

[42] T.-T. You, J.-Z. Mao, T.-Q. Yuan, J.-L. Wen, and F. Xu, "Structural elucidation of the lignins from stems and foliage of Arundo donax Linn.," Journal of Agricultural and Food Chemistry, vol. 61, no. 22, pp. 5361-5370, 2013.

[43] J. Ralph, M. Bunzel, J. M. Marita et al., "Peroxidase-dependent cross-linking reactions of p-hydroxycinnamates in plant cell walls," Phytochemistry Reviews, vol. 3, no. 1-2, pp. 79-96, 2004.

[44] J.-M. Zhou and R. K. Ibrahim, "Tricin-a potential multifunctional nutraceutical," Phytochemistry Reviews, vol. 9, no. 3, pp. 413-424, 2010.

[45] J. L. Rahikainen, R. Martin-Sampedro, H. Heikkinen et al., "Inhibitory effect of lignin during cellulose bioconversion: the effect of lignin chemistry on non-productive enzyme adsorption," Bioresource Technology, vol. 133, pp. 270-278, 2013.

[46] H. Heikkinen, T. Elder, H. Maaheimo et al., "Impact of steam explosion on the wheat straw lignin structure studied by solution-state nuclear magnetic resonance and density functional methods," Journal of Agricultural and Food Chemistry, vol. 62, no. 43, pp. 10437-10444, 2014.

[47] H. Nimz, "A new type of rearrangement in the lignin field," Angewandte Chemie, vol. 5, no. 9, p. 843, 1966.

[48] P. Prinsen, J. Rencoret, A. Gutiérrez et al., "Modification of the lignin structure during alkaline delignification of eucalyptus wood by kraft, soda-AQ, and soda- $\mathrm{O}_{2}$ cooking," Industrial \& Engineering Chemistry Research, vol. 52, no. 45, pp. 15702-15712, 2013. 

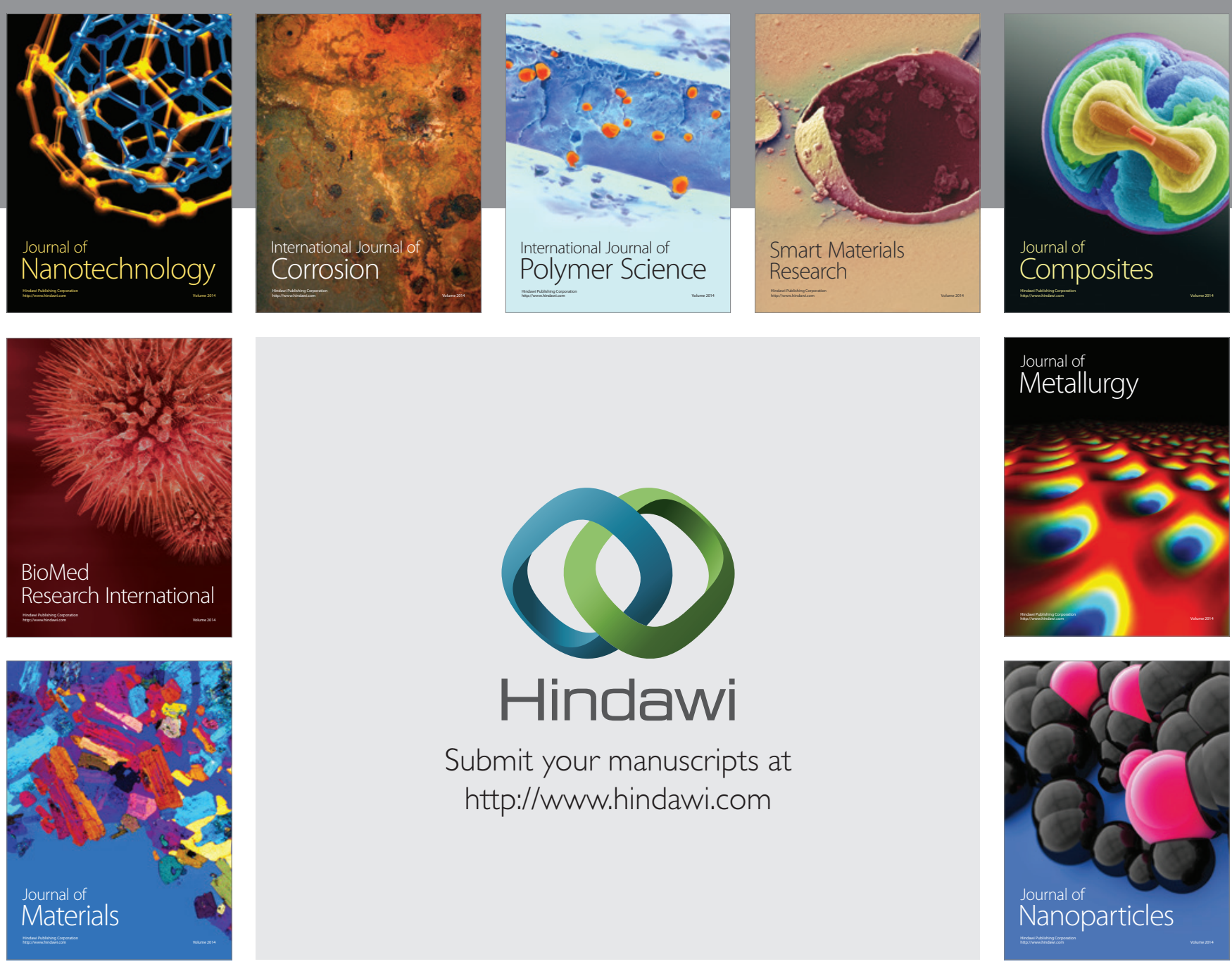

Submit your manuscripts at http://www.hindawi.com
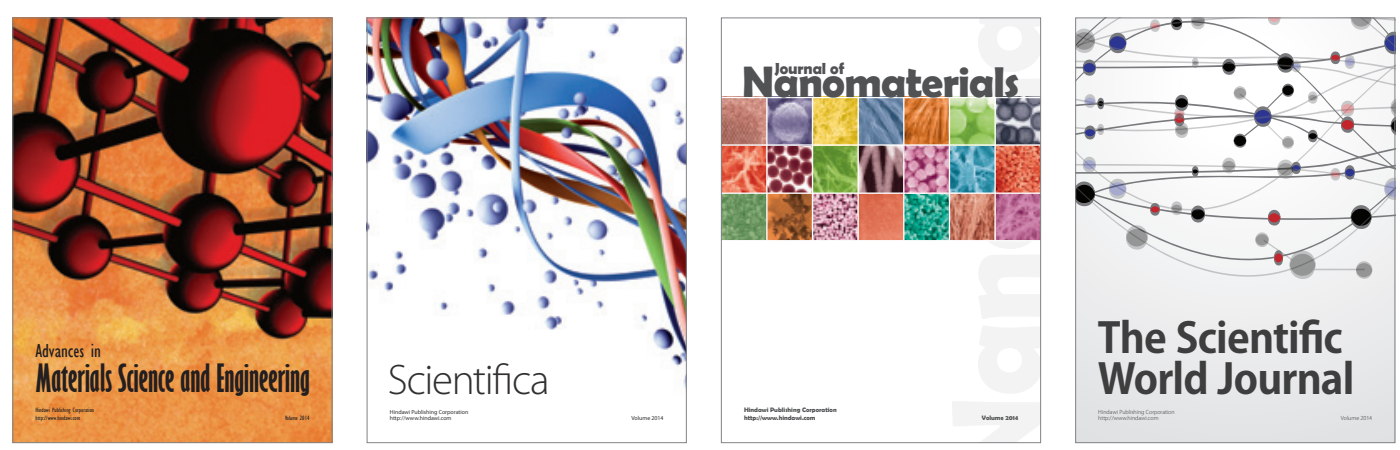

\section{The Scientific World Journal}
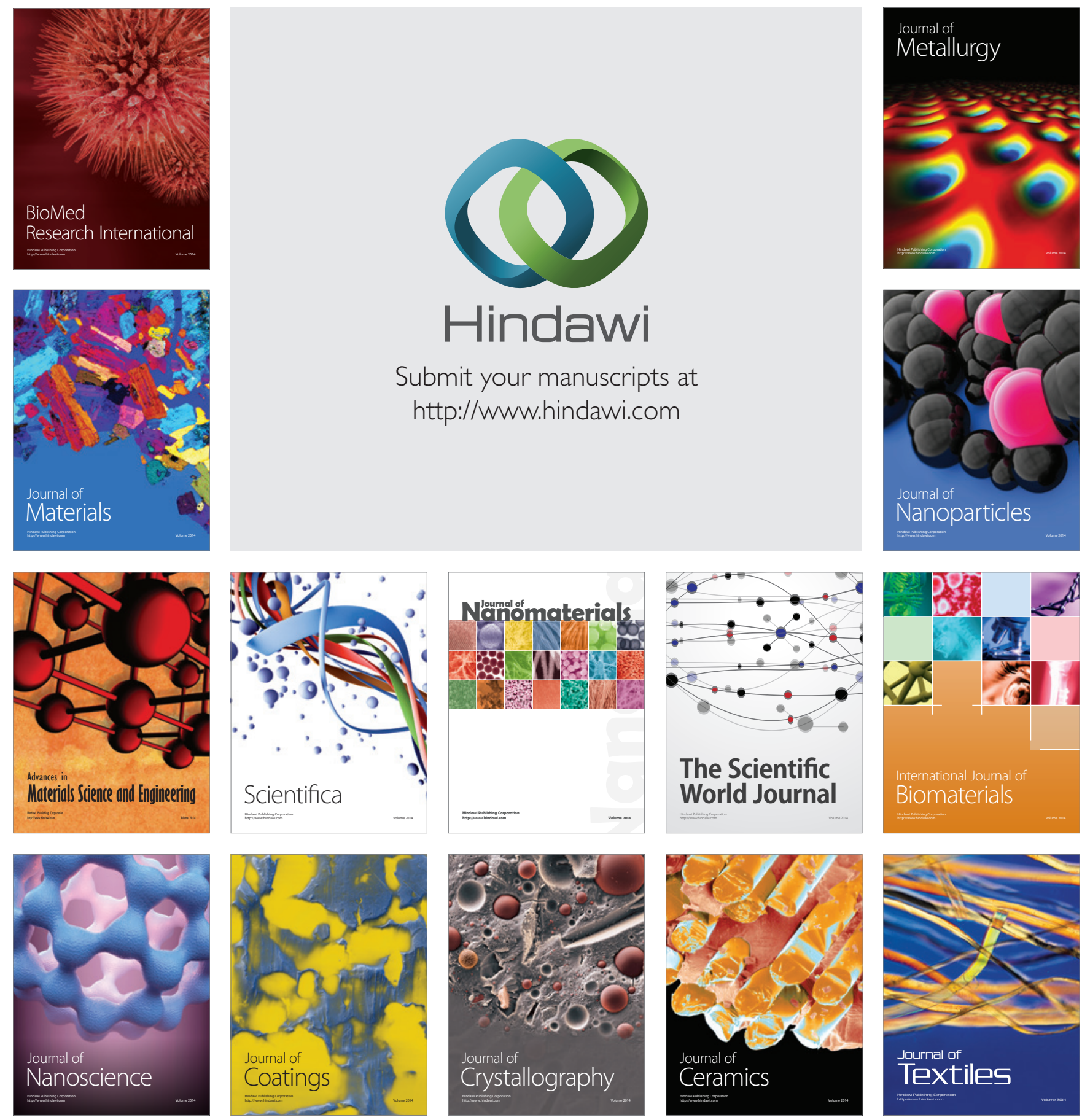